\title{
Social Situation Of
}

\section{Diyarbakir Province}

\section{Throughout The}

\section{Ottoman Domination}

\section{Osmanli Hâkimiyeti Süresince Diyarbekir Eyaleti'nin Sosyal Durumu}

\section{SUMMARY}

Social Stratification can be described as "differentiation of a certain population hierarchically, namely, classes being located one after another in social terms". As at present time, in the past periods as well, one of the most important factors that affected the social stratification was the posts of the persons, that is to say, the occupations and economic power they had. In Ottoman State, human communities living in cities were composed of different groups in general. It has been possible to arrange human groups especially with respect to their jobs or their economical situations and educational positions. As in the other Ottoman cities, in the city and the province of Diyarbakır, those groups constituted the social stratums. In this study, about social stratification in Diyarbakir city and state are given. Family and women issues form the main core of these layers are discussed in detail.

Of the pillars of society throughout history and despite being one of the cornerstones of the nuclear family; this aspect of women in various cultures and periods or have been denied or ignored by hovering, has been reduced to a passive position. Islamic period, together with the woman, a former compared to a more realistic status gained Although, many Muslim states and cultures, traditions from a Ways must be, the status of women of Islam aiming at the level could be reached.

In this study, which is expected to serve as an example to the status of women in the family and provincial organizations, in Diyarbakir Province were discussed between the situation of women in the social structure.Diyarbakir şeriyye sicils, social history and family gives important information about the woman. However, other resources will also be made. However, the issue constitutes the main source of şeriyye sicils.
İbrahim YILMAZÇELIK Prof. Dr.

Firat University, The Faculty of Humanities and Social Sciences, Department of History. iycelik@ hotmail.com

"Beginning by the Seljucks Period, a lot of aşirets (tribes) located especially in the region of Urfa, Mardin and Diyarbakır.

The region maintained this structure within the Ottoman period too. For instance, in 16th century, "Boz -Ulus Aşireti" living in Diyarbakır region, had 7500 houses and 2 million sheeps and goats. Again in this period of time, "Kara-Ulus

Aşireti" was living within the borders of Diyarbakır Province."

Eser Geçmişi

17/05/2016'da başvuru alındı, 19/07/2016'da kabul edildi, 25 Ağustos 2016 'da yayınlandı.

Paper History

Received on 17/05/2016, Accepted on 19/07/2016, Published on 15 August 2016

DOI:

http://dx.doi.org/10.21551/jhf.v2i2.5000189698 
Diyarbakir when dealing with the family's location in the social structure; first marriage and the family traditions and handled accordingly; Formation of the contract of marriage and family (Engagement, religious marriage, civil marriage, mihr, mihr-i müeccel, mihr-i muaccel, namzetlik akçesi, kalın veya başlık), Divorce and varieties, Muslim and non-Muslim in the marriage customs, alimony, and guardian determinations, Muslim and non-Muslim family in the number of children with the Muslim and nonMuslim family in the number of marriages will be discussed. Women's social status is discussed topics will be revealed.

Key Words: Diyarbakir, Women, Status, Family, Ottoman Empire.

\section{ÖZET}

Sosyal tabakalaşma, "belirli bir nüfusun hiyerarşik olarak, yani sosyal manada üst üste gelen sınıflar halinde farklılaşması” şeklinde tarif edilmektedir. Günümüzde olduğu gibi, geçmiş dönemlerde de, sosyal tabakalaşmaya tesir eden en önemli faktörlerin başında, kişilerin bulundukları görevler yani yaptıkları işler ve sahip oldukları iktisadi güç gelmektedir. Osmanlı devletinde şehirlerde yaşayan insan toplulukları, genellikle değişik gruplardan meydana gelmekteydi. Osmanlı şehirlerindeki insan topluluklarını, özellikle yaptıkları işler veya iktisadi durumlarına ve tahsillerine göre sıralamak mümkündür. Bu çalışmada, Diyarbakır şehri ve eyaletindeki sosyal tabakalaşma hakkında bilgi verilmiştir. Bu tabakaların ana çekirdeğini oluşturan Aile ve kadın konusu da ayrıntılı olarak ele alınmıştır.

Tarih boyunca cemiyetin temel direklerinden ve çekirdek ailenin temel taşlarından biri olmasına rağmen; kadının bu hususiyeti çeşitli kültürlerde ve dönemlerde ya inkâr edilmiş ya da görmezden gelinerek, edilgen bir konuma indirgenmiştir. İslamî dönem ile beraber kadın, eskiye oranla daha gerçekçi bir statüye kavuşmuş olmakla birlikte, pek çok Müslüman devlet ve kültürde, gelenekten gelen bir alışkanlıkla olsa gerek, kadının statüsü İslamiyet’in de hedeflediği seviyeye ulaşamamıştır.

Bu çalışmada, taşra teşkilatındaki aile ve kadının statüsüne bir örnek teşkil edeceği düşünülen, Diyarbakır Eyaletinde yaşayan kadınların sosyal yapı içerisinde durumları arasında ele alınmıştır. Sosyal tarih ve dolayısı ile aile hakkında en önemli bilgileri ihtiva eden Diyarbakır Şer’iyye sicillerinden başka kaynaklara da müracaat edilmiştir. Ancak konun ana kaynağını Şer’iyye Sicilleri oluşturmaktadır.

Diyarbakır'da sosyal yapı içerisinde aile'nin yeri ele alırken; öncelikle aile ve evlilik gelenekleri ele alınmış ve buna bağlı olarak; nikâh akdi ve ailenin teşekkülü ( Nişanlılık, dini nikâh, resmi nikâh, mihr, mihr-i müeccel, mihr-i muaccel, namzetlik akçesi, başlık), Boşanma ve çeşitleri, Müslümanlarda ve zimmîlerde evlilik gelenekleri, nafaka ve vasi tayinleri, Müslim ve gayr-ı Müslim ailelerde çocuk sayıları ile Müslim ve gayr-ı Müslim ailelerdeki evlilik sayıları gibi aile’nin sosyal yapı içerisindeki önemini ortaya koyacak konular incelenmiştir.

Anahtar Kelimeler: Diyarbakır, Kadın, Statü, Aile, Osmanlı Devleti. 


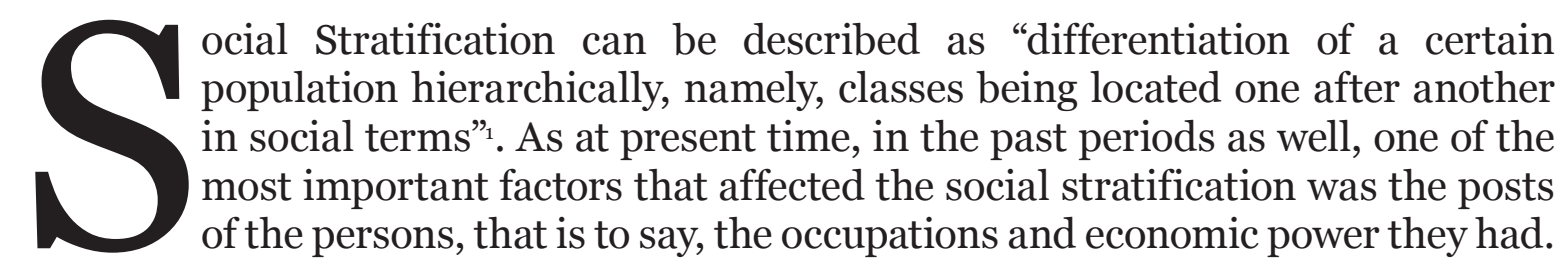

In Ottoman State, human communities living in cities were composed of different groups in general. It has been possible to arrange human groups especially with respect to their jobs or their economical situations and educational positions. As in the other Ottoman cities, in the city and the province of Diyarbakır, those groups constituted the social stratums.

\section{SOCIAL STRATIFICATION}

\section{1-“Yönetici Zümre (Ehl-i Örf)” (administrative class)}

"Umera" (chief administrators), who were appointed by "Padişah" (sultan) and who represented the state, were at the top of the social stratum of Diyarbakir as in all other cities of Ottoman states.

Diyarbakır city was made the province center after being captured by Ottoman state and hence forth, ruled by Pashas (generals) with the rank of Vizier. "Vali" (governor of a province) of Diyarbakır Province, at the same time, was situated as the most foremost administrator ${ }^{2}$. In some conditions, he was bestowed upon Diyarbakır Province. Vali of the province and "Mütesellim" (town governor, tax collector), who was making the province affairs on behalf of "Mutasarrif" (governor of a "sancak"-subdivision of a province), who was the most superior administrative and financial chief of the city where he was charged in, solved not only all the issues of the province, but also the affairs related to the city ${ }^{3}$.

Vali was the foremost person of the chief administrators in the city. Valis of the province resided in "Saray" (palace) in Diyarbakır city and within the period of their post, their entourage called "kapu halkı" helped them in their works. Because of the fact that "kapu halkı" (the entourage of Valis), were quite crowded and about 300 "kapu halkı" were working alongside the Valis of Diyarbakır.

However, excess numbers of these people, paved the way for the complaints from time to time, but any decrease in their numbers were not realized 4 . The persons that were in the service of Diyarbakır Valis, such as Divan Efendisi, Voyvoda, Mütesellim, Tütüncü Ağası, Kapıcılar Kethüdası, Şamdan Ağası, Baş Çavuş Ağa, İç Çukadar Ağa, Kaftan Ağası,

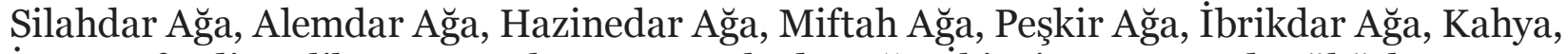
İmam Efendi, Delibaşı, Haytabaşı, Baş Çukadar Ağa, İkinci Kavvas and Mühürbaşı, were

1 Amiran Kurtkan, Genel Sosyoloji, İstanbul 1976, p.149

2 İbrahim Yılmazçelik, XIX. Yüzyılın ilk yarısında Diyarbakır, Ankara, 1995, p.173-184

3 İbrahim Yılmazçelik, XIX. Yüzyılın ilk yarısında Diyarbakır, Ankara, 1995, p.185-192

4 BA., Cevdet Dahiliye, No:2011; National Library, Diyarbakır Şer.Sic., No:356, p.45 
the ones among the foremost persons of administrative class in Diyarbakır city ${ }^{5}$

The Valis of Diyarbakır Province had an income of 20.000 Kurus called "İmdâd-1 Hazariye", which was collected as two installments per year ${ }^{6}$. And that was a considerable amount of money at that period. The income level of the Vali's "kapu halkı" was also higher than those of other groups in the city.

In Diyarbakır City, in case that Valis didn't fulfill their duties in person, "mütesellim" (towngovernor, tax collector) was standing as the foremost person of "Umera" (administrative class). In addition to this; "Voyvoda, ", "Yeniçeri Serdarı", "Kethüda Yeri”, "Kale Dizdarı", "Şehir Kethüdası", "İhtisab Nazırı", "Defter" should be counted as the foremost persons of the city. These officials mentioned above were fulfilling the post of administration together with the Vali or Mütesellim, and were different from the other social groups in many viewpoints. The most important factor, which distinguished this group from the others, was the point that they represented the state in their working areas. In terms of economic power as well, it can be said that these officials as the members of "Ehl-i Örf", had better opportunities than the other groups except wealthy people of the city?

\section{2. "Ehl-i İlim Zümresi” (Class of Scholars)}

As in the other cities, in the city of Diyarbakır "Ehl-I İlim Zümresi”, whose members were generally from "madrasah" (theological school of Muslims) and standing as the assistants of "Ehl-I Örf", constituted the second stratum of the social groups. In Ottoman State, "Kaza", which meant jurisdiction, was performed by "Kadi"(judge of Ottoman court). Parallel to the general practice of Ottoman State in $18^{\text {th }}$ and $19^{\text {th }}$ centuries, jurisdiction issues of the courts in Diyarbakır City, were fulfilled by "Naibs"(vice judges) on behalf of Kadis. In the court of Diyarbakır, in which Naibs, standing at the first place, "Bab Naibi", "Baş Katip", "Katip", "Mukayyid", "Muhzırbaş”, "Nöbetçi” and "Tercüman" were ready, every kind of matters existing in the society were discussed and made decisions about them ${ }^{8}$. Naibs and all officials working in the courts were appointed to their posts with the "Berât" (warrant) of Padishah and besides their duties on jurisdiction; they were the foremost assistants of city administrators. In addition to the court officials, religious functionaries, working in religious institutions, such as "Müderrises" (teachers) of Madrasahs; "Müftüs", who were the assistants of Naibs in many matters; "Nakibü'l-eşraf Kaimmakams", who were charged with the duty of protection of the rights belonging to "Seyyids" and "Şerifs" (descendants of Prophet Mohammed), should be taken into account as the members of this group".

Although the income levels of these people, who were fulfilling the services of carrying

5 Diyarbakır Şer.Sic., No: 229, p.5; No: 590, p. 36; No: 631, p. 21

6 Diyarbakır Şer.Sic., No: 590, p. 40; No:356, p. 59; No: 313, p. 7

7 İbrahim Yılmazçelik, XIX. Yüzyılın ilk yarısında Diyarbakır, Ankara, 1995, p.123-247

8 İbrahim Yılmazçelik, XIX. Yüzyılın ilk yarısında Diyarbakır, Ankara, 1995, p.223-243

9 İbrahim Yılmazçelik, XIX. Yüzyılın ilk yarısında Diyarbakır, Ankara, 1995, p.223-243 
out the religious needs and increasing the cultural level of the people living in the city, were high compared to the city people; it was quite lower than the income level of administrative class. The officials like "Naib" and "Müftü" generally belonged to the native families and had a considerable effect on people, in comparison with the administrative class. Likewise, in this researched period, some of those officials were sent into exile by the state, since they incited the people against the city administrators ${ }^{10}$. The persons, belonging to the group of Ehl-i ilim, constituted the second social group of the city, as they carried out the post of replying the religious and cultural needs of the society by jurisdiction. However, most of these people's economic conditions were quite insufficient compared to the wealthy families of the city. Especially the income level of some persons, being charged in religious and social institutions such as madrasah and mosque, was worse than that of merchants and tradesmen of the city. Yet, as in the example of Mosque Imam, they were among the esteemed persons of the city ${ }^{11}$.

\section{3- The Mediator Class Between the Administrators and the Society}

The mediator class between the "umera" and "ulema" (chief administrators and scholars), charged in the city and the society were composed of the persons called "ayân" and "eşraf" (notables of a region) coming from among the native families of the city.

About the matters concerning the city, opinions of these people were applied. For instance, they participated in "şehir divanı" (city council) that gathered in 1803 for the events, which had occurred in 1802 in Diyarbakır ${ }^{12}$.

Besides this, in the commands and firmans (edicts) sent by state center for the issues concerning the city, the names of "ayan-eşraf" and "vucûh-ı ahâli" were mentioned after the names of city administrators and they were asked for their assistance ${ }^{13}$. This was a crucial practice, which demonstrated that administration was spread to lower groups. Within the researched period, some families belonging to "ayan" and "eşraf" at the beginning; had the right to speak about city administration as the time passed. For example, in this period, in condition that "Şeyhzâde" family was at the first place, the persons belonging to "Gevranlızâde" family were of importance in the administration of the city for a long time ${ }^{14}$. On the other hand, again it is known that some people belonging to this class constituted "vakfs" (charitable foundations, from which people had utilized and through which it had been made considerable aids to the city inhabitants). For example, Hacı Mehmet Ragıp Efendi, who was the son of Mesut Efendi, "Müftü" of Diyarbakır, that played a significant role in the rebellion attempted towards Behram Paşa,Vali of Diyarbakır, 1819, constructed a madrasah building on a vacant land (“... 50 zirâ ve necârî ve arzen 30zirâ irsen ve iştiraken”) belonging

10 İbrahim Yılmazçelik, XIX. Yüzyılın ilk yarısında Diyarbakır, Ankara, 1995, p.247-256

11 İbrahim Yılmazçelik, XIX. Yüzyılın ilk yarısında Diyarbakır, Ankara, 1995, p.241-244

12 Diyarbakır Şer.Sic., No: 356, p. 36-79

13 Diyarbakır Şer.Sic., No: 351, p.14; No: 356, p. 75; No: 299, p. 25

14 İbrahim Yılmazçelik, XIX. Yüzyılın ilk yarısında Diyarbakır, Ankara, 1995, p.192-197 
to himself next to the Defterdar Mosque at Defterdar neighborhood between the years 1833 and 1834 (1249 in Muslim calendar) ${ }^{15}$. In addition that he made over his properties to this vakf for the madrasah, he donated half of the revenue coming from "Hasan Paşa Hanı" (caravansary, khan) that was owned by him ${ }^{16}$. Moreover, Hacı İbrahim Efendi and Hacı Ömer Efendi from ayân constructed a madrasah having six rooms, in the courtyard of Fatih Paşa Mosque in $1807^{17}$. In 1799 Hacı Abdulkadir Efendi built a madrasah at the Çopyan neighborhood as well ${ }^{18}$.

The persons being the members of this class were among the wealthiest people of the city. During the $19^{\text {th }}$ in Diyarbakır only the wealthy persons called "ayân and Eşrâf" were able to have "köle" (slave) and "câriye"(female slave) other than city administrators"1. For instance, a câriye named Meryem brought from Mardin, was sold to Derviş A ğa, belonging to the ayan of the city, in payment for 450 Kuruş, after her being a "Yezidi" was attested in the court ${ }^{20}$. Additionally, when having a look at the total estates of these persons, who were counted as the notables within their neighborhoods in Diyarbakır, it has been possible to determine that they were at a good position compared to the city people. For instance, the value of estate left by Penbeci Hacı Yusuf Ağa, who died on the $5^{\text {th }}$ of May 1788, was 24200 Kuruş ${ }^{21}$, that of Tüccar Hayrettin Ağa, who died on the $6^{\text {th }}$ of April 1792, was 14123 Kuruş ${ }^{22}$, and that of Tüccar Hacı Yasin A ğa, who died on the $9^{\text {th }}$ of July 1800 , was 262280 Kuruş ${ }^{23}$ that this amount of a wealth meant a quite a lot of amount considered in the conditions of the era.

\section{4- Province People}

The society of Diyarbakır was composed of the persons belonging to Islam Religion at first, Judaism, Christianity, and various sects of these religions. This class was the most crowded group in total population and non-Muslims had a ratio of one fifth within this population $^{24}$.

Before giving information about the people living in Diyarbakır, within the social stratification process, it is necessary to give a short information about the "aşirets" (tribes), which had a quite important impact within the population of the district and made

15 VA., Evkaf, No: 2354, p. 55

16 BA., Cevdet İktisat, No: 1083

17 VA., Evkaf, No: 579, p. 135

18 VA., Evkaf, No: 2354, p. 55

19 Diyarbakır Şer.Sic., No: 376, p. 65

20 Diyarbakır Şer.Sic., No: 376, p. 63

21 Diyarbakır Şer.Sic., No: 364, p. 2

22 Diyarbakır Şer.Sic., No: 588, p. 3

23 Diyarbakır Şer.Sic., No: 600, p. 30

24 İbrahim Yılmazçelik, XIX. Yüzyılın ilk yarısında Diyarbakır, Ankara, 1995, p. 115-122 
themselves feel in the district beginning from Turkicizing of Anatolia.

Beginning by the Seljucks Period, a lot of aşirets (tribes) located especially in the region of Urfa, Mardin and Diyarbakır ${ }^{25}$. The region maintained this structure within the Ottoman period too. For instance, in $16^{\text {th }}$ century, "Boz -Ulus Aşireti” living in Diyarbakır region, had 7500 houses and 2 million sheeps and goats ${ }^{26}$. Again in this period of time, "Kara-Ulus Aşireti" was living within the borders of Diyarbakır Province. In $16^{\text {th }}$ century, those aşirets began to bother the native inhabitants and hence they were wished to be resided in the Provinces of Rakka and Halep, but, this attempt was not been succeeded ${ }^{27}$. Aşirets in Diyarbakır Province made a great destruction in the region during "Celâlî Rebellions" existed in Anatolia in the $16^{\text {th }}$ and $17^{\text {th }}$ centuries ${ }^{28}$.

In $18^{\text {th }}$ century, the region, in which the majority of "Aşirets" lived, was again the region of Diyarbakır. In this period as well, some aşirets were intended to be resided in Rakka, yet, it hadn't been managed ${ }^{29}$. In $18^{\text {th }}$ and $19^{\text {th }}$ centuries the places that aşirets mostly lived, were Diyarbakır, Nusaybin, Urfa, Antep and Mardin. For example the numbers of aşirets living in the region of Mardin were thirty in 1747. Between the years of 1790 and 1840 in Diyarbakır Province, the determined numbers of aşirets were thirty. The attempts to reside aşirets living in the region to certain places, continued in $19^{\text {th }}$ century too, but these efforts were partly realized in the second half of the $19^{\text {th }}$ century ${ }^{30}$.

A great portion of people living in Diyarbakır city were occupied with trading, craftsmanship, and farming. Besides this, non-working people, children and women should be considered in this class.

In Diyarbakır, outside the villages, agriculture was made mostly at the coast of the Tigres River and in the west side of the city. The tradesmen groups were, on the other hand, composed of "Bezzaz Cullah, Debbağ, Kassab, Habbaz, Hallaf, Attar, Tütüncü, Sabuncu, Bakkal, Allaf, Kazancı, Palancı, Berber, Boyacı, and so on ${ }^{31}$. Additionally, from the estates and the documents available, it has been possible to determine that, tradesmen of "Sirkeci, Şerbetçi, Tereci, Tuzcu, Mumcu, Mazucu, Lüleci, Bozacı and Camcı" were active in the researched period.

When looking at the estates of a lot of persons from the city people, it would be seen

25 M.Akdağ, Türkiye'nin İktisâdi ve İctimâi Tarihi, Ankara, 1979, C.I, p.24-89

26 M.V.Bruinessen, "The Ottoman Conquest of Diyarbekir and Administrative Organisation of The Province in The $16^{\text {th }}$ and $17^{\text {th }}$, Evliya Çelebi in Diyarbekir, Leiden, 1988, p. 27, Cengiz Orhonlu, Osmanlı İmparatorluğu'nda Aşiretlerin İskan Teşebbüsü, İstanbul, 1987, p. 17

27 C. Orhonlu, a.g.e., p.90-95

28 M. Akdağ, a.g.e. p.463-470

29 Yusuf Halaçoğlu, XVIII. Yüzyılda Osmanlı İmparatorluğu'nun İskan Siyaseti ve Aşiretlerin Yerleştirilmesi, Ankara, 1988, p. 52-78-137-140

30 İbrahim Yılmazçelik, XIX.Yüzyılın İlk Yarısında Diyarbakır., p. 312-320

31 Diyarbakır Şer. Sic., No: 6001, p.37; No: 356, p. 10; No: 346, p. 16 
that they had a very low level of income than as of any other classes ${ }^{32}$. Besides this, it is not possible to say that the city people were in a bad situation. For example, in the last days of October 1824, daily wage of a master of stonemasonry was 120 para (3 kuruş [one para equals one fortieth of a kuruş]), daily wage of a master of carpentry would be given 120 para (3kuruş) and that of a farmer, on the other hand, was 60 para (1,5 kuruş) ${ }^{33}$. In the midst of January 1829, the daily wage of a master of stonemasonry and a master of carpentry increased to 160 para (4 kuruss), and that of a farmer increased to 80 para (2 kuruş) ${ }^{34}$. In the year of 1840, a skilled master of architecture earned 10 kuruş, a skilled master of plastering earned 7 kuruş, a well skilled master of carpentry earned 9,5 kuruş, a semi-skilled master of carpentery earned 7 kuruş and a bad-skilled master of carpentry earned 5 kuruş as their daily wages ${ }^{35}$. In 1840, a well skilled master of carpentery, earning a daily wage of 9 kuruş, was able to buy 21,17 "kıyye"( a weight of 1282 grams) of bread as 17 para per one kiyye and 4,5 kiyye of meat as 80 para per one kiyye ${ }^{36}$. The same master in 1840 was able to buy a "findık altını"(a kind of gold coin), which was measured as 22 karats and 3,27 gram metered, with a four-day period of work ${ }^{37}$. As can be understood from this accounting, it can be said that, city people were at a lower stage as compared with the other three classes, but nonetheless, they had a normal life standard with respect to the conditions of era. By the way, it has to be reminded that, in $18^{\text {th }}$ and $19^{\text {th }}$ centuries, people suffered both from the epidemic diseases, natural disasters occurred in Diyarbakır region and waylay events of bandits ${ }^{38}$.

The persons, belonging to the first two groups within the social stratification system, were more powerful in terms of economic conditions. As parallel to the weakening of Ottoman state, absence of "Valis" and "Kadıs" in their working areas and their administration of the area by the means of their representatives, put the people into a bad situation ${ }^{39}$. Beginning from the $18^{\text {th }}$ century, transforming "mirî mukataa"(renting of land belonging the state treasury) to "mâlikane"(as compatible with the law, leaving a piece of land to someone), paved the way for existence of "ayan-eşraf" class in the provinces and disappearance of the state control over these regions ${ }^{40}$. As in the whole of Ottoman country, in the Province of Diyarbakir as well, these people, beginning to come into scene in that, maintained their presence as "A $\breve{g} a$ " and "Beğ" within the social structure of the region until today. For example, in $18^{\text {th }}$ and $19^{\text {th }}$ centuries, it has been observed that the duty of "mütesellim"(town governor, tax collector) in the province of Diyarbakır was performed by the native families (Şehzade and Gevranlizadeler) and as they abused their duties, the people of the region

32 Diyarbakır Şer. Sic., No: 327-364-588-600-317-319-346-347-377

33 BA., D.BSM.BNE., No: 16311, p. 11

34 BA., D.BŞM,BNE., No: 16355, p. 11

35 Diyarbakır Şer. Sic., No: 607, p. 17-22; No: 352, p. 27

36 M. Öztürk, “Güney Doğu Anadolu'da Fiyatlar”,V.Milletler Arası Sosyal ve İktisat Tarihi Kongresi, Tebliğler, İstanbul-1989, p. 119-120

37 Diyarbakır Şer. Sic., No: 607, p. 24

38 İbrahim Yılmazçelik, XIX.Yüzyılın İlk Yarısında Diyarbakır.,p.109-115

39 İbrahim Yılmazçelik, XIX.Yüzyılın İlk Yarısında Diyarbakır., p.328-480

40 Yücel Özkaya, Osmanlı İmparatorluğu’nda Ayanlık, Ankara, 1977, p.58 vd 
faced to lots of difficulties ${ }^{41}$. Thus, some kinds of events happened in these years occurred as a reaction to the arbitrary practices of the administrators rather than an action against to the state. In the province of Diyarbakır throughout the Ottoman rule, absence of political, religious or ethnic characteristics in such events has confirmed our claims ${ }^{42}$. Besides, it has been known that the state continued to take precautions necessary for the welfare of the people. In $18^{\text {th }}$ and $19^{\text {th }}$ centuries in the province of Diyarbakır, presence of both "Hanefi" and "Şafii" (two sects of Islamic thought) "Müftüs"(the persons who were in charge of Islamic affairs for a province) showed that the state knew the religious situation of the region and respected to this situation ${ }^{43}$.

\section{II- SOCIO-ECONOMIC SITUATION OF FAMILY IN DIYARBAKIR}

It is possible to define family as the small community, which is formed by a married couple and their children. As in ancient times, in the period we have investigated, family constructed the base of the community.

In Ottoman era, family, which constituted the smallest part of the society, was shaped, on one hand, by the former traditions of Turks, and on the other hand, by the rules brought up by Islam Religion. According to former beliefs of Turks, family and the structure of it affected directly the community. In Orhun Inscriptions, ancient Turkish family described with the word of "Oğuş", domination of father was seen. However, father didn't have unlimited rights, in spite of his being the head of the family, when comparing to the other nations like Romans and Arabs, where the father of the family got unlimited rights, women and children didn't have any rights and they were even bought and sold just like a commodity. The father in the family was rather an assistant who, held the held the family altogether and taken them under his protection as well as meeting their needs. Indeed, within the steppe culture, the concept of "nobility" was not seen and as a mater of fact, the life style of ancient Turkish community was not convenient for that ${ }^{44}$.

Family, which had a considerable position in ancient Turkish community, was shaped with the frame of Islamic Law in the period after the acceptance of Islam by Turks, and it was considered as a holy institution first of all and it was restructured by making crucial changes in favor of women. Although father was the head of the family as in ancient Turkish community, he did not have unlimited rights. Woman had both material and spiritual rights over her husband. After Turks accepted Islam, as in the many aspects of life, in the matters related to family as well, "SSer'i Hukuk" (Islamic Law) came in the first place. In addition to that, "Örfi Hukuk" (Traditional Law), which was originated from Turkish organizations

41 İbrahim Yılmazçelik, XIX.Yüzyılın İlk Yarısında Diyarbakır., p.365-367

42 İbrahim Yılmazçelik,"XIX. Yüzyılda Diyarbakır Eyaleti'nde Yönetim Halk Münasebetleri”, Bayram Kodaman'a Armağan, Samsun, 1993, p.371-387

43 İbrahim Yılmazçelik, XIX.Yüzyılın İlk Yarısında Diyarbakır., p. 457-458

44 İbrahim Kafesoğlu, Türk Milli Kültürü, İstanbul,1984,p.201-220; Baheddin Öğel, Türk Kültürünün Gelişme Çağları, II, p.137. vd; Rıfat Özdemir, "Kırşehir'de Aile'nin Sosyo-Ekonomik Yapısı (1880-1906)", Osmanlı Araştırmaları, IX, 1989, p.101-108. 
and traditions as well as the taxation methods and laws of the countries conquered by Turks, had an important place too. However, in Ottoman state, "Örfi Hukuk" (traditional law), which was shaped by "Kanunnâmes" (written laws) had an important place in many matters, except those of the field of civil law. In Ottoman state, the matters concerning family, were usually solved within "Şer'i Hukuk" (Islamic Law) ${ }^{45}$.

1- Muslim and Non-Muslim groups in Diyarbakır

In Ottoman period Muslims coming at first, then Christians and Jews lived in Diyarbakır. Beginning from the $16^{\text {th }}$ century the four fifth of the population was composed of Muslim Turks and the one fifth of the population was composed of Jews and Christian groups such as Armenians, Armanian Catholics, Protestants, Catholic Christians, Keldanis, Süryanis, Yâkubîs, Nasturis ${ }^{46}$. This ratio increased as in the favor $\mathrm{f}$ Muslim population in rural areas.

These groups, which formed the city population of Diyarbakır, lived together in some neighborhoods and lived separately in the others. Most of the neighborhoods of Diyarbakır were Muslim neighborhoods. In $19^{\text {th }}$ century, there were 65 Muslim neighborhoods and 13 non-muslim neighborhoods in Diyarbakır. On the other hand, Muslims and non-Muslims lived together in 42 neighborhoods. Yet, some of these mixed neighborhoods had been separated as Muslims and non-Muslims, in such kind of neighborhoods these groups lived in the same area as separate one from the other. Some neighborhoods, on the contrary, were the ones, in which these groups lived together as a mixture. In neighborhoods like them, the houses or shops of Muslims and non-Muslims were next to each other's and they had maintained their lives without interference to each other ${ }^{47}$.

The relationship of non-Muslim population in the city of Diyarbakır with Muslim people was good and in an unjust situation they had the right to sue ${ }^{48}$. It is known that Ottoman State tolerated them in terms of their religiousbeliefs. And these non-Muslims, thanks to this tolerance, had performed their prayers in this free atmosphere in churches and monasteries and when their rites were meddled, the state suddenly intervened to the situation ${ }^{49}$.

Non-Muslim people had occupied with their own affairs fulfilled their responsibilities and sometimes entered even into partnership with Muslims ${ }^{50}$. By the way, in times of

45 Rıfat Özdemir, “Tokat'ta Aile'nin Sosyo-Ekonomik Yapısı (1771-1810)” Türk Tarihinde ve Kültüründe Tokat Sempozyumu Bildirileri, Ankara, 1987, p. 98-100. Ömer Lütfü Barkan, XV. ve XVI. inci Asırlarda Osmanlı İmparatorluğunda Zıraî Ekonominin Hukukî ve Malî Esasları, Kanunlar I, İstanbul, 1943.

46 İbrahim Yılmazçelik, XIX.Yüzyılın İlk Yarısında Diyarbakır., p. 115-122

47 İbrahim Yılmazçelik;,XIX.Yüzyılın İlk Yarısında Diyarbakır., p. 44-50

48 Diyarbakır Şer. Sic., No: 376, p. 14-18; No: 594, p. 11-27; No: 631, p. 22

49 Diyarbakır Şer. Sic., No: 607, p. 6-7-30; No: 352, p.76-77; No: 356, p.77

50 Diyarbakır Şer.Sic., No: 594, p.10. 
conflict both among themselves and with Muslims, they were able to insist on their rights by applying to the court. For example, on the $19^{\text {th }}$ of 1802 Çarıç̧ı Malkon made a complaint about another non-Muslim named Arakil for his unnecessary occupation of the house belonging to him, and his complaint was accepted, since the house being talked of was understood, by the witnessing of a person named Seyyid Zülfükar, to be owned by Arakil ${ }^{5}$. In December 1826, on the other hand, three non-Muslims from iron manufacturers complained a muslim named Resul b.Ali claiming that he paid for the iron he bought and at the end of the trial they came to an agreement for 600 kuruş $^{52}$. On the2oth of March 1848, Hüseyin Ağa-zâde Hafız Mehmed residing in İzzettin neighborhood of Diyarbakır, applied to the court claiming that he was owed 8995 kuruş by Mihan, who was again a resident of the same neighborhood, Mihan didn't accept this claim and at theend of the trial the complaint was rejected, as two Muslims named Molla Mehmed b.Sait and Hüseyin b.Ali verified Mihan ${ }^{53}$. It is possible to increase the number of these examples. However, as can be understood from the documents mentioned above, non-Muslim people maintained their lives in an exact equality. Moreover, non-Muslims, by applying to the court, carried on their issues, not only the ones related to various conflicts, but also the ones like selling of a house, share of estates, by using the rights provided for the Muslims ${ }^{54}$.

As understood from the estates being seen in Diyarbakır "Şer"iyye Sicilleri” (registrer of Shari a courts), within the searched period, non-Muslim people were at a good position economically as well. The level of life standards of non-Muslim people, who dealt with trade mostly and were active in jewelry tradesmen of Diyarbakır, was better than most of the Muslim people 5 . For instance, the worth of inheritance, that was left by Manim, who died on $13^{\text {th }}$ of July 1800 , was 21496 kuruş ${ }^{56}$. And this was a quite much amount of money in respect to the conditions of that time. In Diyarbakır, non-Muslims had to inform the court about an event of death, just like the Muslim people. The inheritance process would also be carried on according to the Islamic Law. In the midst of August 1836, in an edict by the state addressing to "Amid Naibi" (vice judge of Diyarbakır court), in a situation of a person's death from the non-Muslim people, when registering his estate and sharing his inheritance, "resm" (a kind of tax) was taken and it was mentioned that even one "akçe" (one third of a para) more than the amount; stated as "... binde 15 akçe kalemiye ve ikişer akçe kâtibiye ve hüddâmiye ki ceman 25 akçe olub...” (25 akçe in total); of 25 akçe was not allowed to be taken ${ }^{57}$.

When comparing the estates of the Muslims and non-Muslims living in the city of Diyarbakır in Ottoman period, it will be seen that the names of some materials, such as clothing equipment, living room equipment, bedroom and kitchen equipment, illumination

51 Diyarbakır Şer. Sic., No: 299, s. 54. ,Diyarbakır Şer. Sic., No: 352, p.70., No: 594, p. 31; No: 603, p. 39-40

52 Diyarbakır Şer. Sic., No: 631, p. 7

53 Diyarbakır Şer. Sic., No: 352, p. 108

54 Diyarbakır Şer. Sic., No: 590, p. 29; No: 352, p. 99.; No: 376, p. 14

55 Diyarbakır Şer. Sic., No: 600, p. 23; No: 285, p. 22

56 Diyarbakır Şer. Sic., No: 600, p. 28

57 Diyarbakır Şer. Sic., No: 352, p. 135-136 
equipment, weapons and knives and the aims of their usage were same ${ }^{58}$. It was possible to see the same material, which was available in a Muslim's house, in the house of a nonMuslim. And this should be accepted as an indicator that the people living in this city were jointly together with the exception of some ethnographic differences. This situation has shown us that the non-Muslim people imbibed Turkish culture intensively since they had been living within this culture for a long time. As a result of this influence, it has been observed that some of the non-Muslim people living in Diyarbakır, among whom there were the persons such as Jews, Armenians, and Rums, converted to the religion of Islam from their original religions and registered their conversion to Islam in the courts ${ }^{59}$.

Another indicator of the social lives of these groups living in a region has been the names, which have been given by families according to their beliefs and pleasures. Because of this, in Ottoman period, the names and nicknames used in the city of Diyarbakır have been evaluated as a distinct study ${ }^{60}$. The names most commonly used by Muslim families were the names like; Mehmet, Mustafa, İbrahim, İsmail, Bekir, Ali, Hasan, Hüseyin, Yusuf, Salih, Abdullah, Osman, Feyzullah, Halil, Kasım, Ömer, Veli, Abdurrahman, Ahmed, Hıdır, Şeyhmuz, Zülfükar, Süleyman, Yasin, Emine, Fatma, Hatice, Ayşe, Halise, Nebile, Şerife, Zeynep. It was seen that, Muslim people used rather the names of significant Islamic people or prophets, prophet's daughters and wives. Additionally, it can be said that, there were quite a lot of Turkish names. For example, the names like; Şahin, Kaya, Murad, Hanım, Gazele, Sabuhan, Kahraman, Kutlu, Toğmuş, Tanrıverdi were seen in general. On the other hand, special to this region, it has been observed that some names were shortened as AboAbdullah, Alo-Ali, Simo-İsmail, Memo/Memi-Mehmet, Silo-Süleyman, Şiho-Şehmuz. The most common nicknames used among the Muslim people living in Diyarbakır were the epithets, which designated either the family names or physical appearances or occupations of the persons, like Zâde, Efendi Molla, Şeyh, Paşa, Oğlu, Çavuş, Çolak, Topal, Kel, Demirci, Debbağ, Katırcı, Öksüz, Leblebici, Değirmenci, Alemdar, Çelebi.

The most common names used by non-Muslim families in the region of Diyarbakır, were the names like; Ohan, Ohannes, Serkiz, Manok, Kirkor, Karabet, Bedros, Agop, Meryem, Vartan, Erakil, Esber, Tama, Haço, Baghos, Makdis, Maksi, Eko, Lusi, and Asdos. Just as the Muslim families, non-Muslim families also used for their children the names rather originated from their religions, gave the names of the crucial persons and saints of their religions. Besides this, it is interesting that some of the non-Muslim families living in Diyarbakır gave their children the names like; Sultan, İbrahim, Sadakat, Durmuş, Altın, Murad. As in the Muslims living in the city, in non-Muslims as well the nicknames were the names indicating their occupational and social groups or physical appearences. For instance, the nicknames like; Mazucu, İnce, Değirmenci, Altuncu, Meyhaneci, Oturakçı, Katırcıŏ̆lu, Hallaç, Bezzaz, Kocabaş, Keşiş, can be given as examples. As a result, it can be

58 City documents on this subject are pretty much Diyarbakir Şer'iyye Sicils see. Diyarbakır Şer. Sic., No: 600377-285-328-363-346-319-347-317-588-364-327. However, allowed to make a comparison here to record only four credits will be given the Legacy. see Diyarbakır Şer. Sic., No: 317, p. 8-7; Diyarbakır Şer. Sic., No: 347, p.24-37.; Diyarbakır Şer. Sic., No: 346, p.36-51; Diyarbakır Şer. Sic., No: 363, p.2-4.

59 Diyarbakır Şer. Sic., No: 631, p. 21; No: 607, p. 1-3; No: 351, p. 39; No: 626, p. 1

60 This assessment, almost all of Diyarbakir Şer'iyye Sicils has been considering. 
said that, both the male and the female names used by Muslim and non-Muslim families were rather religious based names and this situation was the outcome of the cultures of these communities, besides this, it showed the cultural interaction between them ${ }^{61}$.

Thus, before examining the various aspects of the family in Ottoman era, the people living in Diyarbakır were studied from different perspectives. As in this part, in the latter topics as well, the Muslim and the non-Muslim people living in Diyarbakır were taken into consideration as a whole, and the family, which was the base of the society, was examined from various aspects within the studied period.

\section{1- Family and Marriage Traditions in Diyarbakır}

\section{a-Marriage Agreement and the Formation of Family}

In Islamic Law, in the event that there was not an obstruction, marriage of a singular male with singular female would be accepted as a religious necessity and family would be considered as a holy institution. The structure of Turkish society was not different from this and Kadı as the head of the Ottoman court would ensure this holiness ${ }^{62}$.

Ottoman state as well, would give a great importance to family and show a significant care to the existence of convenient conditions for the formation of family institution. For example, in 1845, in an edict sent to İsmail Paşa, who was the "Müssir" (Marshall) of Diyarbakır province, it was mentioned that marrying of the singular girls and widows was being obstructed by their parents with various pretexts and this was causing the reduction in the population, so encouraging the marriages of ones like these was asked for. In that edict dated 1845, this issue was explained as “...rü'yet olunduğuna memâlik-i mahrûsâ-yı şahânemin ba’zı kasabât ve kurâsında bâkire kızların babaları ve akrabaları otuz yaşına tezviç itmeyüb zevci fevt olmuş olan hatunların dahi bila muceb-i muharrer durmakta ve bu keyfiyet takllil-i tenasül mü'eddi olmakta bulunmuş olarak hatta bu keyfiet bu def'a kocaili meclisinden bâ-mazbata beyan ve inha olunmuş olduğuna behemehal bu uygunsuzluğun def'i lazım gelmiş...” and nextly, it was asked for interrogation of these parents as “... bundan böyle mani’-i şer’isi yoğiken teçviç tasrih ve beyan kılınmış olub ol misillü bâkire ve sayyibe hâtunların nezd-i sicillerine akraba ve müte'allikâtın biveçh-i şer’i mâni olmaları hilâf-ı şer'-i şerîf olduğun ba'd-ezin ol misüllü kız ve hatunların teçvicine veli ve akrabası tarafından mümâneât olduğu hâlde ma'rifet-i şer-î şerîf ve meclis ma'rifetiyle kendileri celb olunarak sebeb-i muhâlefetleri...” ${ }^{63}$. It is certain that this edict was sent to other provinces of Anatolia as well in the stated time.

61 XVI. In centuries, Muslim and living in Diyarbakır zımmî religious groups rather than a reality with their names are names.. Besides those of Turkish names are being used widely in the region. XIX. century of the information given in the names of individuals, XVI. For comparison with century see. Mehmet Mehdi İlhan, "Onaltınc1 Yüzyıl Başlarında Amid Sancağı Yer ve Şahıs Adları Hakkıda Bazı Notlar” Belleten, LIV. p.221-222

62 Rifat Özdemir, "Harput ve Çemişgezek’te Askeri Ailelerin Sosyo-Ekonomik Yapısı (1890-1919)".Tarih İncelemeleri Dergisi, V, p.52-53

63 Diyarbakır Şer. Sic., No: 392, p.8 
According to Islamic Law, being obvious of the marriage agreement was necessary. As in other Islamic states, in Ottoman state as well, the marriage agreement would be made in the presence of Kâdı and the document of this process would be registered to "Şer"iyye Sicilleri" (registers of Shari'a courts). According to Islamic Law, it was necessary first of all that marrying couples had to use their own free thoughts in this process. The persons, who decided to get married, would come to the court and then make their marriage agreements in the presence of witnesses and this would also be registered to "sicil" (register). In some cases, however, the marrying persons would send their proxies, who were the close relatives of them, to the court or in some cases the marriage would be made within the house, but in both situations the marriage process would be registered to "sicil" (register) ${ }^{64}$. In Diyarbakır "Şer'iyye Sicilleri” (registers of courts), these kinds of marriage documents have been seen. For instance on the $29^{\text {th }}$ of June 1822, Hanife and Yusuf living in Diyarbakir applied to the court and the marriage was made by their own consents in the presence of the witnesses ${ }^{65}$.

In Ottoman period, as in the case of Muslims, non-Muslims were also able to make their marriage agreements in the court. As being free in terms of their religious beliefs, languages and traditions, after getting married acoording to their own rites in the church, they would register their marriage agreements in the court. For instance on the $19^{\text {th }}$ of January 1826, Menoş veled-i Karabet and Serkiz veled-i Ohannes got married with their own consents and the document of this marriage was registered to sicil(register). By the way, the "mehr-i muaccel" (bride-price) of the female was determined as 100 kurus and her "mehr-i müeccel" (the determined price that would be given to female as in the case of her husband's death or divorce) was determined as 100 kuruş to, and this was also registered also to sicil(register) ${ }^{66}$. In another document dated of 1826 , this time marriage of two muslims was seen. On the11th of March 1826, from the residents of Diyarbakır, Hatice and Abdurrahman applied with their own wills to the court and in the presence of witnesses their marriage agreement was made and "mehr-i muaccel and müeccel" were determined as 200 kuruş ${ }^{67}$.

Since the marriage agreement was dependent upon the contests of two sides, in 1830 a woman named Fatma brought a suit against her husband named Halef indicating hat for her uncle named Ali kidnapped a girl, who was the sister of Halef, he gave Fatma to Halef by force, and hence after the marriage agreement became invalid ${ }^{68}$. On the $27^{\text {th }}$ of December 1829, Mola Halil brought a suit against his wife named Cumhure claiming that they got married four years ago and his wife escaped from him and married with another person in the village of Develi, so he wanted the court to give back his wife, but when the

64 Rıfat Özdemir, “Kırşehir'de Aile'nin Sosyo-Ekonomik Yapısı”. p.111

65 Diyarbakır Şer. Sic., No: 351, p.39. see. M.Akif Aydın, “İslâm-Osmanlı Aile Hukuku” , Osmanlı Araştırmaları,III,1982, p.85-101.

66 “.... Amid sakinlerinden zımmiyye Menoş veled-i karabet nam bikrin mani-i şer’isi yoğ ise Serkiz veled-i Ohannes tarafeyn rızaları ve velisi iziniyle lede'ş-şühüd tesmiye-i mihr ve akd-i nikah-1 şer'i edesiz ve's-sellam ....” see. Diyarbakır Şer. Sic., No: 631, p.22

67 “... Amid sakinlerinden Hatice bint-i Mehmed nam bikrin mani-i şer’isi yoğ ise Hamid b. Abdurrahman tarafyn rızaları ve velisi izniyle lede'ş-şühüd tesmiye-i mihr ve akd-i nikah-1 şer'i ide...” see. Diyarbakır Şer. Sic., No: 631, p. 22

68 Diyarbakır Şer. Sic., No: 376 p.15 
woman informed that Halil had kidnapped her by force, their marriage became invalid ${ }^{69}$. In 1830, in a case similar to this, Mehmed b. Ömer applied to the court to bring a suit against Bakkaloğlu Mehmed, accusing him for kidnapping his wife and marriying with her, but in the trial it was understood that Mehmed b. Ömer had divorced his wife and so the trial was rejected ${ }^{7}$. As understood from a document dated of 1829, Ali stated that his wife named Zeyneb abondoned him and he demanded for her turning back o him, but after the woman stated that he had kidnapped her by force, the trial of Ali was rejected either ${ }^{71}$.

In a case, in which two persons from the same religion had been married but then one of the two sides changed his/her religion, the marriage would become invalid. For example, on the $30^{\text {th }}$ of November 1826, a Jewish woman named Elşer accepted the religion of Islam and took the name of Esma, so her marriage with her husband named Yakop was counted as invalid; stated as "... Islam evladı olduğu dahi takririnden nümayan ve kelime-i şehadet getirüb fasih-i eda eylediği..." (because of her converting to Islam) ${ }^{72}$. By the way, a woman, Whose husband had died, was not able to marry with another man until it was understood that she was not pregnant, but after this situation became clearer, she was allowed to get married again ${ }^{73}$. This waiting period was called "iddet müddeti"(in case of divorce a period of 100 days, and in case of the husband's death a period of 130 days).

In the city of Diyarbakır, among the Muslim families, marriage of two persons, who were close relatives, was not observed. In middle Asian Turks, since the blood tie was considered to be an obstacle to the marriage, marriages rather among the non-relative persons was more common. The same situation was valid for Islam religion too ${ }^{74}$. However, as any document was not met, it was not made any interpretation on this issue.

\section{b- Marriage Traditions and Family Institution in Muslims}

In the $19^{\text {th }}$ century, in some cities like Ankara, Çankırı, Konya, and Tokat, it was seen that some parents used to give their little daughters to some persons for an amount of money and when these girls grew up they would be made marry with those men and this practice was called "namzet" 75 . Such a practice was not met in Diyarbakır during the same period.

On the contrary, in the first half of the $19^{\text {th }}$ century, tradition of "başlı" (bride-price)

69 Diyarbakır Şer. Sic., No: 376, p.26

70 Diyarbakır Şer. Sic., No: 376, p.37

71 Diyarbakır Şer. Sic., No: 376, p.57

72 Diyarbakır Şer. Sic., No: 631, p.21

73 Understood from a hüccet dated January 1818, according to Şerife loss of a woman reported that her husband had wanted to leave. She said that bleeding was seen. Were allowed to marry someone else. see Diyarbakır Şer. Sic., No: 590, p.34

74 Rifat Özdemir, “Tokat'da Aile’nin Sosyo-Ekonomik Yapısı, 1771-1810”, p.104

75 Rifat Özdemir, “Kırşehir'de Aile’nin Sosyo-Ekonomik Yapısı”, p.115 
continued and payment in this tradition was able to be made both in cash and in kind. For example, in a document dated of 1830, the statement of "...sagirin babası Hasan anası Fatma'yı akd-ı nikâh idende başlığı mukabili mezkur ahur ile bir re's inek verüb...” (giving a stable and a cow as the bride-price) would be an example to the payment of bride-price given in kind ${ }^{7}$. In another document again dated of 1830, the mother of Ümmü Hatun brought a suit against Ahmed, the husband of Ümmü Hatun, for the reason that he kept his word about the goods, which he had promised to give before the marriage. As a response, Ahmed, by stating as “...150 guruş başlık nâmıyle verdiğini...” (150 kuruş as the bride-price stated that he gave, mentioned that he had given the bride-price and not promised for any goods $^{77}$. As examples to the issue, there are two documents more, dated of 1834. In the first one of these examples, a woman named Ayşe brought a suit against her brother indicating that he had taken the bride-price, stated as “... bir zincir ve bir kuşak ve def'a bir simli zincir doksan adet koyun ve kuzu ve 16000 gurusu...” (a [golden] chain, a belt and a chain made of silver, all of which would be used as jewelry, 90 sheep and lambs and 16000 kuruş), and these things had to be given to her ${ }^{78}$. In the other example, a man named Resul brought a suit against a person named Hacı Süleyman, claiming that Hacı Süleyman had married to his wife Ayşe when he had been to elsewhere. Yet, Hacı Süleyman said that he had married to her by bride-price, stating as “...bir fes, bir re's inek ve 230 guruș sağ para...” (an axe, a cow and 230 kuruss), with the consent of her father and the trial was referred to "fetva" (fatwa, mufti's opinion on a matter involving the Islamic religious law) ${ }^{79}$. As understood from these documents, in this period practice of bride-price was being used.

Bride-price was the money given to the family of the bride candidate. The money given directly to the bride candidate by the groom candidate was called as "mehir". According to the Islamic law, nobody except the bride had the right on this money. Mehir, which had to be given before the marriage or the marriage agreement during the marriage agreement, was called as "mehr-i muaccel" (bride-price) and "mehr-i müeccel" (the determined price that would be given to the woman as in the case of her husband's death or divorce). The amount of this money was changeable according to the conditions of the day, being wealthy or poor of the families and beauty, ugliness, talent of the marrying girl ${ }^{80}$.

Mehir had to be determined as mehr-i muaccel and mehr-I müeccel, during the marrying process in the presence of witnesses. For example, on the $11^{\text {th }}$ of 1826 , while making the marriage agreement of Hatice and Abdurrahman in the presence of witnesses, mehr-i muaccel and müeccel of the bridewere determined as $200 \mathrm{kuruş}^{81}$. As understood from a document dated of 1829, mehir of Zaide, which had been determined as 600 kuruş after her marriage with Bekir, was not paid by Bekir, so he was brought a suit by the mother

76 Diyarbakır Şer. Sic., No: 376, p.10

77 Diyarbakır Şer. Sic., No: 376, p.38

78 Diyarbakır Şer. Sic., No: 594, p.29

79 Diyarbakır Şer. Sic., No: 594, p.114

80 R. Özdemir, a.g.m., s. 112, vd

81 Diyarbakır Şer. Sic., No: 631, p.22 
of Zaide ${ }^{82}$. In another document again dated of 1829, it was seen that Ali had given 250 kuruş as mehir and married to Ayşe, but since his wife escaped, he demanded the money back $^{8_{3}}$. In case of the husband's death or divorce, woman was able to ask for her mehir if she had not taken it earlier. For instance, the amount of 500 kurus as mehir of Hafiz Hüseyin Efendi's wife was paid to the woman by deducting from his estate after his death in the lasts of May $1844^{84}$. At the end of a divorcing process as well, mehir of woman would be certainly paid, if it had not been paid yet, then the woman was able to get her money by applying to the court. For instance, in 1829 a woman named Fatma demanded for her mehir by mentioning that her husband had divorced her, and at the end of the trial 250 kuruş as mehr-i muaccel and 250kuruş as mehr-i müeccel totally 500 kuruş was paid by her husband ${ }^{85}$.

In $18^{\text {th }}$ and $19^{\text {th }}$ centuries, the amount of mehr-i muaccel and mehr-I müeccel, which were the legal rights of women, would change among the amounts of 140-200-250-300400-500-600 kuruşs. When there would be some conflicts between the husband and the wife, they would be asked for solvind these matters kindly and divorce would be considered as the last solution ${ }^{87}$.Additionally, the woman was able to insist on her rights in the case of injustice without divorcing. There are quite a lot of documents related to this issue in "Diyarbakır Şer'iyye Sicilleri” (registers of Sharia courts).

For example in 1830, Şefika Hatun brought a suit against her husband named Hacı Ali, stating that he had taken 400 kuruss from her to buy a house and he hadissued the title deed for the house on himself ${ }^{88}$. The cases like this demonstrated that a woman, when necessary, was able to insist on her rights by applying to the court ${ }^{89}$. In the case of her husband's death, the woman took a share as much as the amount determined by Islamic law, from the estate of her husband ${ }^{90}$. In case of the money's lacking, the woman was able to insist on her rights by applying to the court ${ }^{21}$.The most used method in divorce cases was "talak" (divorce), which was separated as "bâin" (a kind of talak in which the husband was not allowed to return to his wife before the end of three menstruation period (iddet) of her and "ric'î" (a kind of talak in which the husband was allowed to return to his wife within the period of iddet). Talâk-1 Bâin was a practice that gave the chance to the husband for turning back to his divorced wife with only a new marriage. Telâk-1 Ric'î, on the other

82 Diyarbakır Şer. Sic., No: 376, p.30

83 Diyarbakır Şer. Sic., No: 376, p.59

84 Diyarbakır Şer. Sic., No: 377, p.6

85 Diyarbakır Şer. Sic., No: 376, p.4. see. Diyarbakır Şer. Sic., No: 631, p. 9-49; No: 376, p. 6-44-45; No: 351., p. 44

86 Diyarbakır Şer. Sic., No: 376, p. 6-30-32-44-45; No: 351, p.44; No: 631, p.1-9-22

87 R. Özdemir, a.g.e., p.114

88 Diyarbakır Şer. Sic., No: 376, p.25

89 Date in 1830 a woman named Rahile, her husband sued about against see. Diyarbakır Şer. Sic., No: 376, p.2. Date in 1829 woman named Esma, her husband sued about against see. Diyarbakır Şer. Sic., No: 376, p.33.

90 see. R. Özdemir, a.g.m., p.129 vd

91 Diyarbakır Şer. Sic., No: 594, sp 30 
hand, was a practice, which gave the husband the right of turning back to his divorced wife without a necessity of remarrying. In Diyarbakır city, the common method of divorce was the practice of talak. In such cases, the woman was able to bring a suit to her husband for divorce and was able to demend for her mehir and alimony, by applying to the court ${ }^{22}$. For instance, in the midst of March 1826, Esma Hatun applied to the court wishing to divorce from her husband Bezzaz Molla İsmail and since her husband accepted as well her wish, they got divorced. At the end of the trial, her husband accepted to pay 400 kuruş for the price of mehr-i müeccel and to give alimony and clothing money for three months and ten days. In case of her being pregnant from Ismail, the care of child was going to be in the responsibility of him until the child was going to be 7 years old ${ }^{93}$. As understood from a document dated of 1834, Hay Hatun claimed that her husband named Abbas was beating and behaving maliciously towards her, so they were decided to get divorced ${ }^{94}$. On the first days of August 1826, Süleyha bint-i Hâcı Hasan brought a suit against her husband named Sinan and wished to divorce him, stating the cause as “...Sinan Ramazan-I Şerifin ikinci gecesi kumar oynarsam benden talak-ı selase ile benden boş olsun diyü şart ve talik itmekle el-haleti'l-hazihi merkûm Sinan kumar oynayub..." (he was going to divorce from her on the condition of his gambling in Ramazan). Despite the denial of her husband, with the verification of the witnesses, they were divorced by the condition of his giving the price of mehir and alimony for three months and ten days ${ }^{95}$. A divorce case similar to this was seen on the $24^{\text {th }}$ of February 1830. A woman named Emine, who was residing in Câmiü'ssefa neighborhood, brought a divorce suit against her husband for their conversation and the response of her husband stated as “...işbu Ramazan-ı Şerifde somun ekl eylediğinde Müslüman değilmisin somun ekl ediyorsun deyü söylediğimde merkûm dahi Müslüman değilüm diyü..." (she asked the reason of his eating bread, since the time was Ramadan in which people would fast, and asked whether he was a Muslim or not, and he said in his response to her that he had not been a Muslim). At the end of the trial the witnesses verified the woman and then they got married again by the statement of “...tarafeyn rizalariyle tecdid-i iman ve nikah olunup..." (both of them renewed their beliefs and remarried with their consents), and the woman put a condition of divorce in a case that her husband going somewhere else and not returning until the end of one and a half years ${ }^{96}$.

We would like to give two more examples as interesting as this. For example, in 1830 Rahile Hatun brought a divorce suit against her husband Hasan stating the cause as "... merkûm Hasan beni nikâh eylemek murad eylediğinde eğer beni şehirde saklarsan seni alurum köyde saklar isen almam dediğimden merkûm Hasan eğer seni köyde saklar isem benden boş olasun deyü nikâh yapub 12 seneden beri köyde sakladuğundan...” (Although Hasan married with her on the condition that they were going to live in the city after marriage and, if not, their marriage was going to be invalid, he had carried out his permission for 12 years) and their trial was referred to fatwa97. In April 1834, Ümmi bint-i Mehmed brought

92 Diyarbakır Şer. Sic., No: 631, p. 1; No: 351, p. 44; No: 376, p.44-45

93 Diyarbakır Şer. Sic., No: 631, p.9

94 Diyarbakır Şer. Sic., No: 594, p.2

95 Diyarbakır Şer. Sic., No: 631, p. 49

96 Diyarbakır Şer. Sic., No: 376, p. 32

97 Diyarbakır Şer. Sic., No: 376, p. 10 
a divorce suit against her husband Hasan mentioning that she got married with him on the condition that they were going to live in Diyarbakır, but they resided in Ergani and their trial, as well, referred to fatwa ${ }^{98}$.As understood from the documents mentioned above, in cases that the woman did not get on well with her husband, she could apply to the court in order to divorce. Demands for divorce of the women left by their husbands were accepted immediately99. It has been seen that in some cases, men as well applied to the court to divorce from their wives, except the method of talak. For example, a person named Molla Ömer brought a suit against his wife, because she aborted her baby deliberately during pregnancy and the trial was referred to fatwa ${ }^{100}$. Women could take alimony not only in case of divorce, but in the cases that their husbands would leave them and go to other places, as well ${ }^{101}$.

In a case that a married woman furnicated, she was deprived of that right. Zina, “...bir akd-i şeriyeye müstenid olmaksızın bi'l-ihtiyar yapılan haram bir cimâ...” (illegally done sexual intercourse without being married), was prohibited definitely in Islamic Religion. According to Islamic law, it was necessary that the event of fornication was going to be proven without any doubt and at least four male witnesses had to attest this in the presence of Judge. In Ottoman cities, although it was seen a lot of trials concerning with fornication cases in registers, it was not observed any punishments of "recm and hadd" (stoning someone to death has been called "recm" and "hadd" means the certain punishments for certain crimes). This was due to the difficulty of proving the event ${ }^{102}$. For example in the midst of April 1818, a resident of Derviş Hüseyin neighborhood, Züleyha bint-I Ömer, brought a suit against Hüseyin indicating that her little son Mehmed was born as a result of Hüseyin's raping to her with using force and the child was born from such a fornication, so she demanded from the court to perform whatever was the necessary. But her trial was rejected since she was not able to present any witnesses ${ }^{103}$. In April 1834, Osman b.Mehmed, in the suit he brought against non-Muslim İnce Kiryakos, claimed that the wife of Süleyman Efendi and Ince Kiryakos had fornicated, and when this event had been understood Süleyman Efendi had been killed, so he wanted the guilty ones to be punished. The defendants did not accept the accusation, and the trial was referred to fatwa. Hence after, as there were not any witnesses to confirm the claims, the trial of Osman b.Mehmed was decided to be rejected ${ }^{104}$.

It was explained above that women and children were paid a certain amount of alimony in case of the husband's death or his going somewhere else. In April 1818, for example, a woman named Emine brought a suit against her divorced husband and at the end of the trial 24 akçe for alimony and clothing price was determined for their little son

98 Diyarbakır Şer. Sic., No: 594, p. 25

99 Diyarbakır Şer. Sic., No: 376, p. 42

100 Diyarbakır Şer. Sic., No: 376, p. 44

101 Diyarbakır Şer. Sic., No: 376, p. 42

102 R. Özdemir a.g.m., p. 116-117

103 Diyarbakır Şer. Sic., No: 590, p. 33

104 Diyarbakır Şer. Sic., No: 594, p. 33 
Mahmud, and her husband accepted that too ${ }^{105}$. In another document dated of the third of January 1826, a woman, who was divorced from her husband, was ordered to be paid the alimony of 30 kuruş for three months ${ }^{106}$. In another document dated of April 1834, it was decided to be given the little son of a woman named Fatma, the alimony of 15 kuruş as monthly ${ }^{107}$. The alimony was not only paid in case of the husband's leaving the house as well ${ }^{108}$.

In Ottoman society, it has been seen that some precautionary measures were taken for the future of children, whose parents were not alive or who had no one. In such cases a "vasi" (guardian) for the little children was appointed so that he could carry on a go of their jobs and managing all kinds of monetary issues on behalf of them ${ }^{109}$. Those vasis (guardians), who would be appointed to direct the wealth of the children, would be both from among the relatives of the children or someone else determined by the judge from among non-relatives ${ }^{110}$. In Ottoman sate, as convenient to the principles of Islamic law, "vasi"(guardian) and "nazur" (a person appointed to control the activities of vasi) would be appointed for the children, who became orphans after death of their parents, and they could not use the assets inherited to those children arbitrarily. The person appointed as the guardian for the child had to demand for the determination of a certain amount of money as "nafaka" (alimony) and "kisve baha" (clothing price) for the child and the right to use this money, by applying to the court. For instance, in the midst of December 1817, the mother of the girls named Zeyneb and Ümmiye, whose father had died, applied to the court and a daily 16 akçe for alimony and clothing price per each child was determined by the court ${ }^{111}$. The amount of the alimony for the children was changeable according to economic condition of the family. For instance, a document dated of April 1818 for each one of the two boys, whose father had died in that time; it was determined to be given 50 akçe for alimony and clothing price, ${ }^{112}$ whereas in 1824 , for each one of the children, whose father had died, it was determined 20 akçe for alimony and clothing price ${ }^{113}$.

Although, it was cared to the process of appointing a person as the "vasi" (guardian) of the children, in a case of misuse of the authority, the person appointed to manage their assets as vasi would be dismissed immediately ${ }^{114}$. For example, el Hâc Esat Efendi, who was appointed as vasi of İbrahim, who was the little son of Çavuşi Osman b. Abdullah died on the date of the $17^{\text {th }}$ June of 1802 , was discharged for the reason indicated as “...

\footnotetext{
105 Diyarbakır Şer. Sic., No: 590, p. 29

106 Diyarbakır Şer. Sic., No: 631, p. 1

107 Diyarbakır Şer. Sic., No: 594, p. 11

108 Diyarbakır Şer. Sic., No: 351, p. 51. Diyarbakır Şer. Sic., No: 351, p. 44.

109 R. Özdemir, a.g.m., p 12

110 Diyarbakır Şer. Sic., No: 376, p. 34.Diyarbakır Şer. Sic., No: 631, p. 6; No: 352, p. 90). Diyarbakır Şer. Sic., No: 356, p.3)

111 Diyarbakır Şer. Sic., No: 590, p. 26

112 Diyarbakır Şer. Sic., No: 590, p. 32

113 Diyarbakır Şer. Sic., No: 351, p. 52

114 Diyarbakır Şer. Sic., No: 594, p. 3-32
} 
vesâyet-I merkûmenin idâresinden âciziyeti izhâr eylediğinden başka sağir-i mezbûrun mâlını emvâline hıfz etmette..." (his being incapable of managing and also his adding the assets of the child to his own assets), and instead of him, Mehmed b. Osman was appointed as vasi (guardian) ${ }^{115}$. The children being under the guardianship, after coming to a certain age, would demand for the abolition of the guardianship by applying to the court, so the guardianship would be abolished ${ }^{116}$. In some cases, on the other hand, a "kayyım" (representative) would be appointed for the persons, whose being alive or dead was not known, to manage their assets and after the children reached puberty, his duty would end $^{117}$.

As understood from the information above, within the frame of Islamic law, the family was evaluated as a holy institution and for the continuity of this, various precautionary measures wee taken. In cases of divorce and death, on the other hand, some precautionary measures were taken by some kind of practices which could be evaluated as the kinds of social security institutions of that time providing the comfort for the children.

\section{c- Marriage Traditions and Family Institution in Non-Muslims}

The non-Muslims living in the Ottoman administration had an exact liberty in terms of their languages, religious beliefs and traditions, so they solved their many matters related to family law within their own community ${ }^{118}$. However, they solved some of their problems by applying to the court. For example, on he $19^{\text {th }}$ of January 1826 , Menoş veledet-i Karabet and Serkiz velet-I Ohannes applied to the court with their consents to get married and they were married in the presence of witnesses. Besides this, mehr-i muaccel as 100 kuruss and mehr-i müeccel as again 100 kuruş were determined and registered to the sicil (register) ${ }^{119}$.

The period of "Nişanlllık" (engagement) of the boy and the girl before the marriage, being seen in Muslims, was seen among non-Muslims as well. For instance, as understood from a document dated of 1830, a non-Muslim man named Oseb brought a suit against a non-Muslim woman named Sadakat, indicating the reason as "...patrik ve keşişleri marifetiyle nişan dahi verilüb ayinleri üzerine, patrik-i mersûm tarafından memhûr kâğıd verilmesinden sonra ..." (after the engagement process, which was made in the presence of Patriarch and Monks) since she stated to change her opinion on the idea of engagement, he demanded the necessary processes for marrying with her to be done ${ }^{120}$.This trial was referred to fatwa and (about the result of it) we have not got any information about the result of it, yet, the importance of this case was its being an example of engagement tradition, which was present among non-Muslims as well.

\footnotetext{
115 Diyarbakır Şer. Sic., No: 299, p. 5

116 Diyarbakır Şer. Sic., No: 590, p. 22

117 Diyarbakır Şer. Sic., No: 376, p. 3

118 R. Özdemir, “Tokat'ta Ailenin Sosyo-Ekonomik Yapısı”, p. 107

119 Diyarbakır Şer. Sic., No: 631, p. 22

120 Diyarbakır Şer. Sic., No: 376, p. 5
} 
In Diyarbakır province as well, non-Muslim people could utilize from the easiness as well, which were provided to Muslims in making the marriage agreement and some other issues. In this period, just as Muslims, non-Muslim people also paid a certain amount of money called "resm-i gerdek" (a kind of marriage tax). Although it has not been possible to determine the amount of "resm-i gerdek" paşd for a marriage agreement by Muslims, we determined the amount paid by non-Muslims. In 1845, in a command registered to Harput sicili, it was stated as “...Ermeni reâyâsının gerdekleri vukû̀unda resm-i gerdek ve arûsaneleri te'diyede kusurları..." (in the payment of resm-i gerdek by Armenian people there was not seen any mistakes), it was demanded to prevent the situation, stated as “... ziyâde talebi ile rahatsız oldıkları beyânıyle ..." (their being hurt by the demand for the extra money). Again from this command, “...ihtisâb vaz’ olunan mahallerde Ermeni re’âyâsı gerdeğivukû'unda âlâ kâğıd alanlardan otuz ve evsât kâğıt alanlardan yirmi ve ednâ takımından onar gurûş..." (30 kuruş from rich people, 20 kuruş from the people of average wealth and 10 kuruş from the poor people for their formal procedures), the amounts of resm-i gerdek from different groups were notified ${ }^{121}$. This money, paid with the name of resm-i gerdek in the marriages of non-Muslim groups living in both Diyarbakır and other cities of Anatolia, was abolished in1846-1847(1263 in Islamic calendar) by an edict sent to all cities ${ }^{122}$. It has been known that the non-Muslims living in Diyarbakır in this era utilized the principles of Islamic, as in a case of death of a child's mother and father, a vasi would be appointed for the orphans and vasi could apply to the court for determination of a certain amount of alimony ${ }^{123}$. For example, in the midst of November 1817 , the children of a nonMuslim, died in the Şeyh Matar neighborhood of Diyarbakır were given, for the reason of their being little, under the guardianship of a non-Muslim named Marin veled-i İko ${ }^{124}$. In early Ocyober 1826, on the other hand in a suit on alimony and clothing price, brought by the little daughter of a non-Muslim named Entoş again in Şeyh Matar neighborhood, it was determined an amount of 60 akçe foe a day as the alimony and clothing price of the little $\operatorname{girl}^{125}$.

As can be understood from the information above, the non-Muslims living in Diyarbakır city, utilized the opportunities provided by Islamic law, while they were maintaining their own traditions. In this period, we determined that the non-Muslims utilized from the rights provided to Muslims in the issue s like marriage, mehir, vasi tayini (appointment of a guardian), and alimony within the Islaic law, but we could not see any documents demonstrating their practices in the issues of divorce and bride-price.

121 Harput Şer. Sic., No: 392, p. 9. In some places in this order 'the official said has been taken up a penny resm-1 gerdek. “... ber müceb-i kanun alınması lazım gelen onbeş ve otuz akçe resm-i arusane zaman-1 atik icabınca müretteb-i devlet-i râic-i vakte nazaran pâre-dûn idüğü ve bir guruş ahzı dahi mugayir-i ma'adelet-i seniyye olacağına binâen kânûnda muharrer onbeş ve otuz akçeye mukâbil onbeş ve otuz guruş resm...” Should not receive more tax.

122 Harput Şer. Sic., No: 392, p. 47.

123 Diyarbakır Şer. Sic., No: 631, p. 55

124 Diyarbakır Şer. Sic., No: 590, p. 24. 
d- The Marriage Situations and the Numbers of Children in Muslim and Non-Muslim Families in Diyarbakır

According to the Islamic law, although the father was the chief of the family, firstly the woman had some rights upon her husband and then the children as well had some rights on their father. As it is known in the religion of Islam, unequal treatment among the sons and daughters was prohibited and this issue was tied to some legal principles. On the other hand, in some assumptions of the Islam religion, bearing of mothers was encouraged for growing of the Muslim population, whereas in some assumptions development of family structure in a planned manner was supported ${ }^{126}$. By the way, according to Islam Law, by the presence of a valid justification, a person would be allowed to marry with at most four women, on condition that he was going to provide an absolute equity among them. However, since providing such a definite equity among the women was put as a precondition, which was quite hard to manage, it was seen that monogamy was preferred rather than this kind of a polygamy. By the way, despite the absence of a definite assumption, because the nonMuslims groups did not assent to polygamy, it was not seen any person among the nonMuslims having more than one wife ${ }^{127}$.

It is a known reality that the issues mentioned above, would change according to the conditions of different places. Because of this, the answers to be given to the questions of "how many children did the families living in the city of Diyarbakır during Ottoman period have? How was the distribution of those children as daughters and sons? Was polygamy or monogamy preferred among the Muslim and non-Muslim groups living in Diyarbakır city?", are going to show one more aspect of the Muslim and non-Muslim families in Diyarbakır and hence it will give the opportunity to approach to the issues related to Muslim and non-Muslim families living in Diyarbakır. In Ottoman period, the only source , which could bring up both the marriage situations and the numbers of children belonging to Muslim and non_muslim families living in Diyarbakır city, has been the registers of "tereke" (estate), which have been available in "şer'iyye sicilleri" (registers of sharia courts).

As it is known, registers of estates are the ones, which were registered after the death of a person. For this process, "kadı" (judge) or "naib" (vice judge) would go to the house of the dead person, call for the inheritors or, if not, the representatives of the dead person and write all of the movable goods and immovable properties with their current values to the "sicil" (register). Moreover, the credits and debits, if any, would be registered too. After the debts and expenses were deducted from the inheritance, the rest of the inheritance would be shared among the inheritors. The shares of young, disabled and sick ones would be delivered to "vasiler" (guardians), and in the case that there was not any vasi available, somebody among the inheritors, who was reasonable and reliable, would be appointed as vasi. In a case that the dead person did not have any inheritors, his estates would be inherited by "Beytü'l-mal” (state treasury).

As explained above, registers of estates were the documents, in which the worldly possessions of a died person were divided and distributed according to the conditions of 
Sharia. Registers of estates clarify the situation of its registration time. Since there has been a sharing process, it is not considered that the inheritors do not appear. In the same way concealing of assets, debts and credits is not considered. However, those registers are the documents belonging to the cases which were formally registered, not to the whole area. Because of this, it is not true to generalize a situation by investigating the estate documents, which illustrate the cases existing in a year, and population and marriage situations of a city, and make them common for the whole city in that year. There has not been certain measure in the selection of estate documents based to bring up the quantity of children and marriage situations of non-Muslim and Muslim families living in the city of Diyarbakır, instead a certain proportion of these documents from among the whole of them has been selected at random. Those selected estate documents have been subjected to evaluation andit has been tried to reach to general results. For example from Diyarbakır "şer'iyye sicili" (register of the court), which includes the years between 1826 and 1827, numbered in the inventory as 319, 11 Muslim estate documents and 6 non-Muslim estate documents have been based upon ${ }^{128}$. The reason for selecting more estate documents belonging to Muslims is that, in "Kassam" registers (the documents registered by an official, who would divide the inheritance among the inheritors and protect the rights of young ones.), the estate documents of Muslims are than those of non-Muslims. However, since the Muslim and non-Muslim groups have been evaluated separate from each other, it can be said that it is unimportant not selecting those documents in the same amount for Muslims and non-Muslims. And it should be reminded again that in the selection of those documents belonging both to Muslims and non-Muslims, it has not been taken a certain measure but rather they have been selected at random.

80 estate documents of Muslims and 40 estate documents of non-Muslims have been selected as the examples in order to designate both number of children and marriage situations of Muslim and non-Muslim families living in Diyarbakur between the years 1787 and 1848.13 "Diyarbakır Şer"iyye Sicili" (registers of courts) have been searched thoroughly and it has been seen that in the estate documents within the "Diyarbakır Şer'iyye Sicilleri", the number of those documents belonging to Muslims is quite a lot of more than that of non-Muslims and in a place it has been seen that three fourth of these documents available in registers have belonged to Muslims. The amount of Muslim population and non-Muslim population living in Diyarbakır in that period has not been taken into consideration and a ratio of fifty percent has been determined, so 80 estate documents of Muslims and 40 estate documents of non-Muslims have been taken. By the time, in the process of selecting estate documents, a certain chronology has been followed. According to this, 1 estate document of Muslims and 1 estate document of non-Muslims for the years 1787-1792 $2^{129}$, 2 estate documents of Muslims for the years $1790-1791^{130}, 3$ estate documents of Muslims for the years $1791-1792^{131}$, 10 estate documents of Muslims and 8 estate documents of non-

128 Diyarbakır Şer. Sic., No: 319, Müslim aileler için see p. 4-14-15-16-22-24-26-32-36-44-61. Zimmî aileler için see. p. 18-20-37-39-41-52

129 Diyarbakır Şer. Sic., No : 364, For Muslim families see. p.2, For zımmi families see. p.4

130 Diyarbakır Şer. Sic., No : 327, p. 54-149

131 Diyarbakır Şer. Sic., No : 588, p. 2-3-23 
Muslims for the years 1799-1800 ${ }^{132}$, 11 estate documents of Muslims and 7 estate documents of non-Muslims for the years 1804-1807 $7^{133}, 2$ estate documents of Muslims and 6 estate documents of non-Muslims for the years 1821-1823 $3^{134}$, 13 estate documents of Muslims and 6 estate documents of non-Muslims for the years 1824-1825, 11 estate documents of Muslims and 6 estate documents of non-Muslims for the years 1826-1827 ${ }^{135}$, 12 estate documents of Muslims and 4 estate documents of non-Muslims for the years 1830-1832 $2^{136}$, 5 estate documents of Muslims and 4 estate documents of non-Muslims for the years 1835-1836 $6^{137}, 2$ estate documents of Muslims and 1 estate documents of non-Muslims for the years $1836-1837^{138}, 5$ estate documents of Muslims for the years $1840-1841^{139}, 3$ estate documents of Muslims and 2 estate documents of non-Muslims for the years $1844-1845^{140}$; have been selected. The number of children and the marriage situation in the Muslim and non-Muslim families living in Diyarbakır city between the years of 1787 and 1845, have been presented below, according to both 80 estate documents of Muslims and 40 estate documents of non-Muslims mentioned above.

Table I.

The Number and Sexuality of the Children of Muslim Families Living in Diyarbakır Between the Years 1787-1845

\begin{tabular}{|c|c|c|c|c|}
\hline & Number of & Sons & Daughters & Total number of the \\
\hline Families with one child & 7 & 5 & 2 & 7 \\
\hline Families with two children & 9 & 12 & 6 & 18 \\
\hline Families with three children & 29 & 50 & 37 & 87 \\
\hline Families with four children & 19 & 37 & 39 & 76 \\
\hline Families with five children & 10 & 33 & 17 & 18 \\
\hline Families with six children & 3 & 7 & 11 & 14 \\
\hline Families with seven children & 2 & 8 & 6 & 8 \\
\hline Families with eight children & 1 & 5 & 3 & 278 \\
\hline TOTAL & 80 & 157 & 121 & \\
\hline
\end{tabular}

132 Diyarbakır Şer. Sic., No : 600, Müslim; p. 2-7-13-16-17-18-20-25-30-33. Zımmî: p. 14-16-23-27-28-31-35

133 Diyarbakır Şer. Sic., No : 317, Müslim p. 8-11-17-19-29-54-74-77-82-88-90. Zımmî: p. 7-25-27-48-50-6981.

134 Diyarbakır Şer. Sic., No : 285. Müslim : p. 7-14-18-20-24-28-34-39-50-55-60-61-68. Zımmî, p. 5-22-42-4559-65.

135 Diyarbakır Şer. Sic., No : 319. Müslim, p. 4-14-15-16-22-24-26-32-36-44-62. Zımmî, p. 18-20-37-39-41-52

136 Diyarbakır Şer. Sic., No : 346, Müslim, p. 4-5-6-23-27-34-36-39-40-44-50. Zımmî, p. 25-39-47-49

137 Diyarbakır Şer. Sic., No : 363. Müslim, p. 2-3-21-30-32, Zımmî, p. 4-7-10

138 Diyarbakır Şer. Sic., No : 328, p.6-13, Zımmî, p. 21

139 Diyarbakır Şer. Sic., No : 353

140 Diyarbakır Şer. Sic., No : 377, Müslim, p. 5-68-96, Zımmî, p. 2-9 
As understood from the table above, in Diyarbakır between the years 1787 and 1845, it has been seen that Muslim families had approximately 3 or 5 children. When the total amount of the children is divided by the number of the families, the number resulted from this calculation becomes 3,475 and this proves that the number of children changed between 3 and 5. In the city of Diyarbakır, it can be said that there has been $n$ equality in terms of the amount of sons and daughters of Muslim families. 16 families, from among 80 families taken as modals, had only sons and 7 families had only daughters. It has been seen that, although the quantity of sons have been a little bit more than that of daughters, it can be said that it is not a significant amount at all. The number and sexuality of the children of non-Muslim families have stood as in the table below, according to the situations of 40 families taken as examples.

Table II.

The Number and Sexuality of the Children of non-Muslim Families Living in Diyarbakır Between the Years 1787-1845

\begin{tabular}{|l|l|l|l|l|}
\hline & Number & Sons & Daughters & \multicolumn{1}{c|}{ Total } \\
\hline Families having no child & 5 & - & - & - \\
\hline Families with one child & 11 & 5 & 6 & 11 \\
\hline Families with two children & 17 & 15 & 19 & 34 \\
\hline Families with three & 5 & 10 & 5 & 15 \\
\hline Families with four & 2 & 5 & 3 & 8 \\
\hline \multicolumn{1}{|c|}{ TOTAL } & 40 & 35 & 33 & 68 \\
\hline
\end{tabular}

As can be understood from the table above, in this period of time the non-Muslim families living in Diyarbakır had approximately 1 or 2 children. When the total number of the children is divided by these 40 families taken as modals, the number of 1,7 as the result of this calculation exists and this proves that the number of children changed between 1 and 2 in non-Muslim families. By the way, we have not met with families having not any children among the Muslim families selected from estate documents, whereas 5 families having not any children have been seen among the non-Muslim families. In addition to this, despite being rare, families with 6, 7 or 8 children have been met among Muslim families. However, families having more than four children have not been seen in nonMuslims.

When looking at the number and the sexuality of the children of non-Muslim families, it can be said that there is a balance among the sons and daughters in terms of their quantities, as in the case of Muslim families. From the families taken as the examples, 7 families had only daughters and 8families had only sons. Additionally, in terms of sexuality, 
the number of sons in Muslim families have been a little bit more than the number of daughters, but it can be said that among the non-Muslim families, there has been an exact equality in terms of the quantity of their sons and daughters. After the issue of amount and sexuality of the children in both Muslim and non-Muslim families was explained in this way, we can pass through the information about the marriage situations of them.

According to 80 estate documents selected as examples for Muslim families and 40 estate documents for non-Muslim ones between the years 1787 and 1845, the marriage situations of these groups have been given in table III.

\section{Table III.}

The Marriage Situations of Families Living in Diyarbakır Between the Years 17871845

\begin{tabular}{|l|l|l|l|l|}
\hline & Muslim & \multicolumn{1}{|c|}{$\%$} & Non-Muslim & $\%$ \\
\hline The number of men & 63 & 78,58 & 40 & 100 \\
\hline The number of men & 17 & 21,25 & - & - \\
\hline
\end{tabular}

As understood from the table above, in this period monogamy was rather common among both Muslim and non-Muslim groups in Diyarbakır. In this period any men were not seen being married with two women among the non-Muslim groups. And this should be related to the religious beliefs and traditions of these groups. Besides this, although monogamy was prevalent among Muslims, persons married with two or even three women were seen. For instance, as understood from a document dated of 1830, a Muslim named Barut-Zade Tatar Ramazan, who had died in the stated year, had been married with three women named Amış Hatun, Ayşe and Esma Hatun, and after the death of Tatar Ramazan, his inheritors brought a suit by applying to the court against the brother of Tatar Ramazan named Hacı Mehmet Ağa, claiming that he took too much money from their husband's inheritance ${ }^{141}$. As can be seen from this document, in the city of Diyarbakır there were people being married with three women in Muslim groups. But this situation was nt so common, and as can be seen from the table above, the men being married with one woman constituted the majority. Because of this, as in the other cities of Anatolia, Turks living in Diyarbakır city preferred monogamy, contrary to misinformation about the issue. Despite some exceptions, among the Middle Asian Turks, the tradition of monogamy can be claimed to continue in the period after the acceptance of Islam by Turks. Moreover, although in the province of Eastern Anatolia, the opinion of polygamy's being prevalent in Ottoman

141 Diyarbakır Şer. Sic., No: 376, p. 21. For two women who married Muslim see. Diyarbakır Şer. Sic., No: 352, p. 108 ; No: 376 , p. 34 
period, has been put forward as a popular idea, the registers belonging to Ottoman era have brought up the invalidity of this opinion. Within this period, marriage with two women was seen among Muslim groups living in Diyarbakır, but it was not so prevalent as the monogamy. In non-Muslim groups, on the other hand, any case of marriage with two women was not seen. As a result, it has been observed that Muslim families had 3 or 5 children on the average and for the non-Muslim families the number of children changed between 1 and 2, and it can be said that monogamy was the prevalent practice for both of the groups.

In Ottoman period, Muslim and non-Muslim groups maintained their lives, without so many conflicts among them. Non-Muslims, with the deep influence of Turkish families, with whom they had lived together for a long time, were affected by Turkish culture and they demonstrated that they imbibed Turkish culture on a large scale in that period as giving the names used by Turks to their children and using the similar equipment in their own houses.

\section{REFERENCE}

\section{I- ARCHIVE RESOURCES}

\section{Başbakanlık Osmanlı Arşivi}

Cevdet Tasnifi

Cevdet İktisat, No: 1083

Cevdet Dâhiliye, No: 2011

Bab-ı Defter-i Baş Muhasebe Defterleri Tasnifi

Bab-1 Defter-i Baş Muhasebe Nüzul Emini

D.BŞM.BNE., No: 16311

D.BŞM,BNE., No: 16355

Milli Kütüphane Arşivi

Diyarbakır Şeri'yye Sicili No:

$\begin{array}{llllllllllll}229 & 285 & 299 & 313 & 317 & 319 & 327 & 328 & 346 & 347 & 351 & 352 \\ 353 & 356 & 363 & 364 & 376 & 377 & 392 & 588 & 590 & 594 & 600 & 603 \\ 607 & 626 & 631 & & & & & & & & & \end{array}$

Harput Şeri'yye Sicili No: 
392

\section{Vakıflar Genel Müdürlüğü Arşivi}

Evkaf Defteri: No: 2354

Evkaf Defteri: No: 579

\section{TETKİK VE GENEL ESERLER}

AKDAĞ, Mustafa, Türkiye’nin İktisâdi ve İctimâi Tarihi, C.I , Ankara, 1979

AYDIN, M. Akif,"İslâm-Osmanlı Aile Hukuku” , Osmanlı Araştırmaları, III, 1982, p. 85-101.

BARKAN, Ömer Lütfü, XV. ve XVI. inci Asırlarda Osmanlı İmparatorluğunda Zıraî Ekonominin Hukukî ve Malî Esasları, Kanunlar I, İstanbul, 1943

BRUINESSEN, MartinVan, “The Ottoman Conquest of Diyarbekir and Administrative Organisation of The Province in The $16^{\text {th }}$ and $17^{\text {th" }}$, Evliya Çelebi in Diyarbekir, Leiden

HALAÇOĞLU, Yusuf XVIII. Yüzyılda Osmanlı İmparatorluğu'nun İskan Siyaseti ve Aşiretlerin Yerleştirilmesi, Ankara, 1988

İLHAN, Mehmet Mehdi, “Onaltıncı Yüzyıl Başlarında Amid Sancağı Yer ve Şahıs Adları Hakkıda Bazı Notlar” Belleten, LIV. p.213-232

KAFESOĞLU, İbrahim, Türk Milli Kültürü, İstanbul,1984

KURTKAN, Amiran, Genel Sosyoloji, İstanbul 1976

ÖĞEL Baheddin, Türk Kültürünün Gelişme Çağları, II, Ankara 1988

ORHONLU, Cengiz Osmanlı İmparatorluğu'nda Aşiretlerin İskan Teşebbüsü, İstanbul, 1987

ÖZDEMİR, Rıfat, “Harput ve Çemişgezek’te Askeri Ailelerin Sosyo-Ekonomik Yapısı (1890-1919)".Tarih İncelemeleri Dergisi, V, p.41-123

ÖZDEMİR, Rıfat, “Tokat’ta Aile'nin Sosyo-Ekonomik Yapısı (1771-1810)" Türk Tarihinde ve Kültüründe Tokat Sempozyumu Bildirileri, Ankara, 1987, p. 81-144.

ÖZDEMİR, Rıfat; “Kırşehir'de Aile’nin Sosyo-Ekonomik Yapısı (1880-1906)”, Osmanlı Araştırmaları, IX, 1989, p.101-157 
ÖZKAYA, Yücel. Osmanlı İmparatorluğu’nda Ayanlık, Ankara, 1977

ÖZTÜRK, Mustafa “Güney Doğu Anadolu'da Fiyatlar”,V.Milletler Arası Sosyal ve İktisat Tarihi Kongresi, Tebliğler, İstanbul-1989, p. 99-121

YILMAZÇELIK, İbrahim, „XIX. Yüzyılda Diyarbakır Eyaleti’nde Yönetim Halk Münasebetleri”, Bayram Kodaman'a Armağan, Samsun, 1993, p.371-387

YILMAZÇELİK, İbrahim, XIX. Yüzyılın ilk yarısında Diyarbakır, Ankara, 1995 